DOI https://doi.org/10.30525/978-9934-26-179-4-32

\title{
РІШЕННЯ ВЕРХОВНОГО СУДУ ЯК ОПОСЕРЕДКОВАНЕ ДЖЕРЕЛО АДМІНІСТРАТИВНОГО ПРАВА
}

\author{
Петрик В. Б. \\ старший викладач кафедри адміністративного права та \\ адміністративного прочесу факультету № 3 \\ Інститут з підготовки фахівців для підрозділів Нацуінальної поліиії \\ Львівського державного університету внутрішніх справ \\ м. Львів, Украӥна
}

Перш за все варто зазначити, що Верховний Суд - це найвищий суд у системі судоустрою України, який забезпечує сталість та єдність судової практики у порядку та спосіб, визначені процесуальним законом.

Верховний Суд переглядає судові рішення місцевих та апеляційних адміністративних судів у касаційному порядку як суд касаційної інстанції, а також Верховний Суд у визначених випадках може виступати судом першої або апеляційної інстанції.

Відповідно до ч. 5 та ч. 6 ст. 13 Закону України «Про судоустрій i статус суддів»: «Висновки щодо застосування норм права, викладені у постановах Верховного Суду, є обов'язковими для всіх суб'єктів владних повноважень, які застосовують у своїй діяльності нормативноправовий акт, що містить відповідну норму права. Висновки щодо застосування норм права, викладені у постановах Верховного Суду, враховуються іншими судами при застосуванні таких норм права» [1].

Виходячи із зазначеного, постанови Верховного Суду $\epsilon$ обов'язковими для органів публічної адміністрації, що особливо виокремлює їх значення як джерел адміністративного права. Цікавим являється те, що якщо для суб'єктів владних повноважень ці висновки, які містять правові позиції Верховного Суду є обов'язковими, то всі інші суди повинні їх враховувати при застосуванні відповідних норм права. Слід зауважити, що словосполучення «враховуються іншими судами» означає, що суд не зобов'язаний слідувати правовій позиції Верховного Суду щодо застосування тісї чи іншої норми права, проте у випадку незгоди чи у зв'язку 3 неможливістю іiі застосувати у конкретній справі, суд повинен це обгрунтувати у прийнятому рішенні.

Відповідно до проведеного аналізу судових рішень, що містяться в Єдиному державному реєстрі судових рішень можливо впевнено констатувати значиму роль у судовому правозастосуванні рішень Верховного Суду України. 
Згідно із ст. 346 Кодексу адміністративного судочинства України (далі - КАС України) суд, який розглядає справу в касаційному порядку і бажає відступити від висновку щодо застосування правової норми у подібних правовідносинах передає справу на розгляд палати, об'єднаної палати або Великої Палати Верховного Суду (залежно від того, у якому складі розглядається справа) з метою формування єдиної правозастосовчої практики.

Отже, у цьому випадку суд касаційної інстанції «передає» справу, що означає обов'язок передати справу для необхідності вироблення єдиної судової практики. При цьому суд, що розглядає справу у складі колегії чи палати має право передати справу на розгляд Великої Палати Верховного Суду, якщо справа «містить виключну правову проблему i така передача необхідна для забезпечення розвитку права та формування єдиної правозастосовчої практики» [2].

Із запровадженням обов'язковості рішень Верховного Суду для судів та суб'єктів владних повноважень, які застосовують відповідну норму, у науковій літературі зазначається, що «фактично йдеться про запровадження судового прецеденту» [3, с. 38]. В. В. Ільков вказує, що приймаючи висновки щодо застосування норм права, викладені у постановах Верховного Суду, суд реалізується нормативну функцію. Такі висновки мають особливі ознаки нормативності» [4, с. 355].

Допускаю вважати, що постанови Верховного Суду мають ознаки саме правозастосовчого прецеденту, а не прецеденту у розумінні англосаксонського права, адже вони $є$ прикладом застосування норм права, а не формування нових. Звичайно у правових позиціях Верховний Суд може вийти за межі норми права, якщо існує правова прогалина чи $\epsilon$ необхідність застосувати аналогію закону чи права, конкретизувати правову норму.

Варто звернути увагу на певну неузгодженість щодо можливості відступити від правової позиції Верховного Суду, що передбачена лише для суду касаційної інстанції. Проте $\epsilon$ випадки, коли рішення апеляційної інстанції $є$ остаточним і не може оскаржуватись у касаційному порядку, наприклад, з приводу оскарження рішень, дій чи бездіяльності суб'єктів владних повноважень щодо притягнення до адміністративної відповідальності (ст. 286 КАС України). У такому випадку справа не дійде до касаційної інстанції і суд апеляційної інстанції лише «враховує висновки щодо застосування норм права, викладені у постановах Верховного Суду» відповідно до ч. 5 ст. 242 КАС України [2]. При цьому як для суду першої, так й апеляційної інстанції не передбачено жодних правових наслідків, коли суд навіть необгрунтовано або взагалі без жодних мотивів відступає від правової позиції Верховного Суду. 132 
Підставою для оскарження рішення є передбачена лише щодо типових адміністративних справ, коли суд не врахував правові висновки, викладені у рішенні Верховного Суду за результатами розгляду зразкової справи (ст. 291 КАС України). Це підкреслює «обмежену обов'язковість» правових позицій Верховного Суду. Необхідно також зазначити, що для осіб приватного права взагалі не передбачено їх «обов'язковості», яка може мати лише опосередкований характер, адже при судовому розгляді спору суд може врахувати правові позиції Верховного Суду і тому вони будуть мати вплив на конкретних учасників судового процесу. Проте така їх «опосередкована нормативність» не дозволяе віднести рішення Верховного Суду до джерел адміністративного права у їх класичному розумінні.

Отже, рішення Верховного Суду не можливо назвати джерелом адміністративного права у класичному його розумінні, проте постанови Пленуму Верховного Суду хоча формально не $\epsilon$ обов'язковими, проте беруться до уваги судами і часто використовуються як джерело права.

При розгляді справ, суди повинні враховувати правові висновки Верховного Суду, а також рішення в зразкових адміністративних справах. Правові позиції Верховного Суду є обов'язковими для всіх суб'єктів владних повноважень, що застосовують відповідну норму. Тобто такі рішення мають похідний характер від норми закону, проте на відміну від джерел переконливого характеру, мають враховуватись у судовому правозастосуванні.

Так, все вище зазначене дозволяє зробити висновок, що рішення Верховного Суду, хоч і не являються джерелом права в класичному розумінні, проте займають особливе місце у системі джерел адміністративного права.

\section{Література:}

1. Про судоустрій і статус суддів : Закон України. Верховна Рада України. URL: hhttp://zakon5.rada.gov.ua/laws/show/1402-19/print144603492 8519902.

2. Кодекс адміністративного судочинства України. Верховна Рада України. URL: http://zakon3.rada.gov.ua/laws/show/2747-15.

3. Лічман Л. Г. Значення судової практики для правозастосування у цивільному судочинстві України. Вісник Верховного Суду Украӥни. 2011. № 6 (130). С. 38.

4. Ільков В. В. Джерела права в адміністративному судочинстві України: дис. ... докт. юрид. наук : 12.00.07 / Дніпропетровський державний університет внутрішніх справ. Дніпро, 2017. С. 355. 